\title{
The Relationship between the Applicability of Neuromarketing and Competitiveness: An Applied Study on Real-Estate Marketing Companies in Egypt
}

\author{
Hebatalla Mohsen' ${ }^{1}$ Eman Mahfouz Mostafa ${ }^{2}$ \\ ${ }^{1}$ Collage of Business Administration, Tabuk University, Tabuk, KSA \\ ${ }^{2} \mathrm{New}$ Cairo Higher Institute of Management and Computer Sciences, Cairo, Egypt \\ Email: halbaqa@ut.edu.sa,eman_mahfoz44@yahoo.com
}

How to cite this paper: Mohsen, H., \& Mostafa, E. M. (2020). The Relationship between the Applicability of Neuromarketing and Competitiveness: An Applied Study on Real-Estate Marketing Companies in Egypt. Open Journal of Business and Management, 8, 2006-2028.

https://doi.org/10.4236/ojbm.2020.85123

Received: July 14, 2020

Accepted: August 29, 2020

Published: September 1, 2020

Copyright $\odot 2020$ by author(s) and Scientific Research Publishing Inc. This work is licensed under the Creative Commons Attribution International License (CC BY 4.0).

http://creativecommons.org/licenses/by/4.0/

\begin{abstract}
The knowledge about the brain and therefore the interest in the topic of neuromarketing have increased in recent years. Therefore, this paper aims to study the relationship between the applicability of neuromarketing and competitiveness on real estate marketing companies in Egypt, and to identify the relationship between requirements and factors associated with the marketing activity related to the application of neuromarketing and competitiveness in real estate marketing companies, and to identify the relationship between technical factors, that contributes to the application of neuromarketing and competitiveness in real estate marketing sector. The research hypotheses were adopted based on the previous studies, and based on variables of the study. The researchers tried to identify the relationship between the application of neuromarketing and competitiveness in real estate marketing companies. The researcher used the descriptive analytical method; the data was collected through field research (questionnaire) among 120 respondents. The results show that there was a significant positive correlation between the application of neuromarketing and competitiveness. And also there was a significant positive correlation between the application of neuromarketing activities and competitiveness, and also there was a positive correlation between the application of neuromarketing technology and techniques and competitiveness. The study recommended that real estate marketing companies should focus on competitiveness by enhancing the application of neuromarketing activities and techniques to ease the access to the customers.
\end{abstract}

\section{Keywords}

Neuromarketing, Neuromarketing Activities, Neuromarketing Applications, Competitiveness 


\section{Introduction}

In the present digital age, the customer journey traverses along both digital and physical realms; the true challenge for marketers is unlocking the mysteries of consumers taste and preferences over certain products. It has been a methodological challenge for companies understanding the way consumer's process messages and modeling cognitive responses to advertising messages (Shukla, 2019: p. 267). Marketing plays an indispensable role in initiating novel innovations or translating customer needs into various channels of innovations (Verhoef \& Leeflang, 2009). The much-hyped field in cognitive sciences, neuromarketing still in its nascent stage, also referred as an "embryonic field", is seeking lot of attention in both scientific and marketing community, Neuromarketing-or consumer neuroscience-resorts to methods and research in sights regarding the human brain, seeking to learn and solve problems in the marketing field. By means of advanced neurology techniques applied in the field of consumer neuroscience, a more direct understanding and view of the consumer's "black box" is possible (Solomon, 2008).

The term Neuromarketing was first used in 2002 by a German Professor Ale Smidts (Orzan et al., 2012). However, according to Roebuck (2011) and Krajinovic et al. (2012), the discipline's founder is Professor Gerry Zaltman from Harvard University who conducted a first fMRI (functional magnetic resonance imaging) study as a marketing tool way back in 1999. Neuromarketing was actually the first term used to reference the intergration of neuroscientific methods and economic decision-making models in 2002 (Ramsoy, 2014). Neuromarketing emerged as an expanded field of research on neuroeconomics (Pop et al., 2014). Neuromarketing is on the border between neurosciences and economy and attempts to explain the decision making process by developing a neural model (Egidi et al., 2008).

In recent times, "neuromarketing" has come to mean the application of neuroimaging techniques to market products and allowed us to more fully understand human behaviour in an extremely important context (Lee, Broderick, \& Chamberlain, 2007). Understanding human behavior also requires knowledge of the brain functions. The brain can be divided in three parts: the new brain, the middle brain and the old brain. The body of research that demonstrates the prevalence of the old brain in the decision making process is overwhelming. But the problem is how to address the old brain (Renvoise \& Morin, 2007)? The knowledge about the brain and therefore the interest in the topic neuromarketing have increased in recent years. There are two main reasons for this increase: First, the possibility that neuroimaging will become cheaper and faster than other marketing research methods; and second, the hope that neuroimaging will provide marketers with information that is not obtainable through conventional marketing research.

(Ariely \& Berns, 2010) There is a lot of evidence why the second reason is very important. Ninetyfive per cent of the decisions people make are made by the 
subconscious and only five per cent of the decisions are concious ones (van Arendonk \& Polderman, 2013). Traditional marketing tools are trying to understand the five per cent, but neuromarketing tools are trying to identify the other ninety five per cent. Because of this high percentage neuromarketing has attracted increasing attention, but critical aspects of it remain underexplored, including what exactly it is or includes, and how it is used in practice (Fisher, Chin, \& Klitzman, 2010). Furthermore several neuromarketing findings have been published, yet there is a lack of clarity concerning the use of neuromarketing tools in the area of marketing research.

In recent years, the application of neuroscientific techniques to the study of emotional and cognitive responses of consumers has been growing, and is seen as one of the main areas of studies on consumer behaviour for the future, and a great asset for companies to improve their communication with consumers (Murphy et al., 2008).

This field becomes increasingly interesting to both researchers and the market, as it provides more reliable information than that obtained through traditional marketing methods such as consumer behaviour and the rationalisation of decision making (Vlăsceanu, 2014a, 2014b). However, Stanton et al. (2016) indicate that, with the growth of the field, criticisms and fears of neuromarketing's purported power have grown, including both immediate effects on individual consumers and long-term effects on society as a whole, including positive rights to privacy, autonomy, and dignity as well as negative rights not to be deceived, subjected to experiments without consent, or used as a means only Moreover, Garcia and Saad (2008) state that the neuromarketing field of research does not possess an overarching theoretical framework to guide its research agenda. Amore recent discussion provided by Ulman et al. (2015) declares that further scientific research is still needed in order to establish a stronger basis for the validation of the scientific background of neuromarketing. Nonetheless, Agarwal and Dutta (2015) believe that consumer neuroscience itself has been able to address all concerns of the critics, promising to further emerge as a more rigorous scientific discipline.

According to Dinu et al. (2010), new consumer behavior study techniques should contribute to decision making through the use of information to facilitate this process in order to identify the real reasons for the purchase that should cause a major upheaval in the companies, making these further focus their research on consumer behavior. It means that the development of the collaboration between neuroscience and marketing researchers can help advance knowledge in several key areas, not only related to consumer decisions, but also on how we interact, relate, and behave in the present context of markets and organizations, being fundamental to the success of any market initiative (Lee et al., 2007).

Neuromarketing emerged on the background of traditional marketing methods' not are being deemed satisfactory any more, not only by scientists, but 
also by the business area. Therefore, the need to find a new, much more accurate, stricter and scientifically proven data collecting method for the business environment emerged. Measuring the brainwaves may reveal consumers' subconscious responses to marketing stimuli (Ariely \& Berns, 2010; Calvert \& Thensen, 2004; Kenning \& Linzmajer, 2011; Morin, 2011; Pradeep, 2010).

At present, neuromarketing provides information which cannot be retrieved by means of classical marketing. The most obvious advantage neuroimaging techniques provide is related to the fact that these techniques which harvest quantitative data may also be used before launching a new product, thus increasing the chances of success for that particular launching. Classical marketing methods, such as, focus groups, preference questionnaires, simulated choice methods and market tests are methods which harvest qualitative, subjective data, which do not carry the same accuracy degree regarding the decision-making process as neuromarketing does (Ariely \& Berns, 2010).

And one of the most important sectors facing a lot of competition is the real estate marketing sector in Egypt, if real estate marketing services require that companies work to develop their capabilities and services in a manner that suits the nature of competition prevailing in this sector. Therefore, this study endeavor discuss the relationship and impact between nervous marketing activities as one of the recent trends in marketing methods practices and its role in enhancing the competitiveness of real estate marketing companies.

Especially in light of the rapidly increasing global business scene witnessing competition and seeking to attract the largest possible number of customer segments and increasing the marketing share, which is what our Arab institutions need, especially with the lack of Arab studies that dealt with the competitiveness of real estate marketing companies in dealing with the nervous marketing method.

\subsection{Statement of Problem}

For real estate marketing companies to keep its maintenance and gain customer satisfaction and loyalty in the complex and competitive market of today, they should pay more attain to apply neuromarketing as a new marketing strategy that help in recognizing the thoughts, needs, And feeling of their customers. Thus, it could be easier to meet their needs to achieve customer loyalty and retention, so consequently real estate marketing companies can save its market share, accordingly the statement of the problem can be stated in the following questions.

\subsection{Research Questions}

\section{Main Question:}

1) What is the impact of the application of neuromarketing on the competitiveness of Egyptian real estate marketing companies?

\section{Sub Questions:}


1) What are the requirements and factors associated with the marketing activity related to the application of neuromarketing?

2) What are the technical factors that contribute to the application of neuromarketing?

\subsection{Research Objectives}

The general objective of this study is to explore the relationship between the application of neuromarketing and competitiveness Egyptian real estate marketing companies?

From the perspective of the marketing and sales processes department staff of (real estate marketing).

Particularly the study seeks:

1) To identify the relationship between requirements and factors associated with the marketing activity related to the application of neuromarketing and competitiveness in real estate marketing companies

2) To identify the relationship between technical factors that contributes to the application of neuromarketing and competitiveness in real estate marketing sector

\subsection{Research Importance}

The importance of the current study is due to several considerations that gain academic and applied importance for the following reasons:

1) Lack of foreign and Arab studies that dealt with the topic of application of neuromarketing and competitiveness of Egyptian Real estate marketing companies.

2) Today, neuromarketing has surfaced as a relatively new and insufficiently explored branch of marketing that focuses on the consumer's subliminal reactions to marketing material, brands, products and product groups.

3) Most of the time, the failure of a company's products or business is the difference between what the consumer expects from the products and what the company provides the consumer This implies that, before the company starts business, they should know very well what the consumer expects Evans et al (2006) noted that for a company to be market oriented it needs to be able to identify their customers, how they think and what they respond to. Once there is a deviation from what the consumer expects from the product or business, failure becomes inevitable. Now, neuromarketing bridges this gap in the sense that it provides a complete and accurate analysis and investigation of the standards that the consumer wants; thereby placing such products at a competitive edge. Neuromarketing, not only saves companies' time but it also saves the money, and decreases the risk of a possible product failure. Receiving the attention, emotional engagement and memory directly from the subconscious brain obviously gives neuromarketing a clear competitive advantage in the market place, (Bernal, 2012). 


\subsection{Limitation of the Study}

This research is limited by the nature of the participants where it was conducted on Employees in the marketing department of real estate marketing companies, Convenient sampling technique has been used for the collection of data from the respondents; thus, the generalization of the results should be looked carefully.

The present study has adopted two dimensions of neuromarketing as suggested in previous studies taking in consideration the circumstances of employees in marketing department of real estate marketing companies in Egypt. For this, a total of 26 parameters belonging to these 2 dimensions we are used to measure the responses of the employees about neuromarketing. There may still a possibility of adding some new dimensions or some more parameters to the existing dimensions.

\subsection{Hypothesis of the Study}

This research aims To identify the relationship between requirements and factors associated with the marketing activity related to the application of neuromarketing and competitiveness, and To identify the relationship between technical factors that contributes to the application of neuromarketing and competitiveness in real estate marketing sector, and in order to be able to test these variables, and Based on the previous studies, the researcher proposes the following hypotheses:

\section{Main Hypothesis}

$\mathrm{H}$ : There is a significance relationship between the application of neuromarketing and competitiveness in real estate marketing companies.

\section{Sub hypotheses:}

$\mathrm{H}(\mathrm{a})$ : There is significance relationship between the application of neuromarketing activities and competitiveness.

$\mathrm{H}(\mathrm{b})$ : There is significance relationship between the application of neuromarketing technology and techniques and competitiveness.

\subsection{Conceptual Definition of Study Variables}

\section{1) Neuromarketing}

Neuromarketing is the study of the cerebral mechanism to understand the consumer's behaviour in order to improve the marketing strategies (Smidts, 2002) Neuromarketing is the application of findings from neuroscientific consumer research within the scope of managerial Practice (Hubert \& Kenning, 2008).

Neuromarketing refer to a commercialized market research method for studying brain activity that combines the methodologies of neuroscience and behavioural psychology to generate greater understanding about how consumers respond to products, brands, and advertising stimuli. These insights are then used to inform the development of advertising strategies that are designed primarily to "nudge" particular demographic groups or population segments to take con- 
sumptive action (Nemorin \& Gandy Jr., 2017).

\section{2) Neuromarketing Activities:}

The marketing actions carried out by the institutions through consumers' brain researches to identify factors, variables and motivations, whether in demographic, psychological, behavioural, mental or emotional terms that associated with the purchase decision or preferences for certain brands (Wyer Jr. \& $\mathrm{Xu}, 2010)$.

\section{3) Neuromarketing Techniques:}

The methods and devices used in the field of neuromarketing alongside the marketing activities related to consumer behaviour and variables associated with it. The overall goal of using neuromarketing techniques is to understand the interconnection between marketing activities and the response upon that from consumers (Kumlehn, 2011).

\section{4) Competitiveness:}

Related to the activities and aspects that enable the real estate marketing companies to achieve excellence from competitors by providing service quality, using methods that meet the needs of customers, occupying a market share and increase continuously, distinction prices from competitors, increasing profit and productivity efficiently and effectively (Al-Muharrami, 2009).

\section{Research Methodology}

\subsection{Research Design}

The descriptive-analytical approach was used in the research. Data has been collected through different means which include:

\section{Secondary resources:}

To introduce the conceptual literature of neuromarketing and competitiveness, the researcher has depended on books, periodicals, articles, published papers and referred previous studies in different countries which have been conducted on the same subject, the Internet sites and the available electronic versions.

\section{Primary resources:}

A questionnaire has been used as a primary tool for gathering data from the employees of Real estate marketing companies.

\subsection{Study Population/Sample}

The population of the study consists of the employees of marketing and sales processes of Real estate marketing companies.

The sample consists of total of (120) employees who are patronizing marketing and sales processes departments of Real estate marketing companies.

\section{Sampling Method/Sample Size:}

Convenient sampling technique has been used for the collection of data from the respondents, the convenient sampling method has been used (120) Questionnaires administered to the respondents. All (120) questionnaires were dully 
filled and returned.

\subsection{Data Collection Instrument}

The study employed a questionnaire as an instrument for data collection The questionnaire included 14 statements about Neuromarketing Activities, refer to study of (Lee et al., 2007) 12 statements about Neuromarketing Techniques and 15 statements about competitiveness, refer to study of (Fugate, 2008). A 5-point Likert scale was used to enable the respondents to indicate their level of agreement or disagreement regarding each statement. The study was conducted over 4 months' time period.

\subsection{Statistical Analysis}

The gathered data was interpreted through SPSS 20.0. The relationship between variables was tested through regression, correlation and other descriptive analysis. Whereas, the data collecting tools were also checked for reliability and validity using SPSS 20.0

\section{Previous Studies}

1) Suomala et al. (2012), "neuromarketing: Understanding customer subconscious responses to marketing" the study presents neuromarketing as a way to detect brain activation during customer engagement, This article uses neuromarketing to study how customer engagement is managed by salesperson behaviour and in-store marketing assets.

The researchers established a Virtual Customer Journey model based on the consultative selling process to study customer engagement by using brain scans. Consultative selling suggests that a customer's shopping experience is managed by the salesperson's behaviour and in-store marketing assets, and that the customer gets engaged step by step, A total of 16 test subjects were shown video clips and still pictures from a consultative sales process at Nokia's flagship stores, and their brain activity was scanned. The results show that test subjects were able to associate themselves with people and events on the video and they felt safe and comfortable during the consultative selling process. The study implies that laboratories can build virtual environments that resemble real shopping environments where customers can participate in the buying process and respond to events displayed on the screen, and that neuroimaging is useful in providing valuable information on customer behaviour that is not achievable otherwise.

2) Sebastain (2014), "New directions in understanding the decision-making process: Neuroeconomics and neuromarketing" this study showed that Neuroeconomics and neuromarketing are new emerging interdisciplinary fields at the interface between neuroscience, psychology, economics and marketing. Relatively contiguous, they are studying how we make decisions, one in an immersive context, the economic one and the other, customizing, is focusing on how consumers make the decision to buy. Within this article were approached two 
new lines in understanding the decision making process, namely neuroeconomics and neuromarketing. Both disciplines highlight the link between the decision-making process and the brain regions involved in its development. Using neuroscience specific methods, these two disciplines offer a new vision of the decision-making process.

3) Shukla (2019), "Neuromarketing: a change in marketing tools and techniques"

This paper seeks to identify the various tools and techniques used in conventional research and consumer neuroscience with its pros and cons. The purpose of this article is firstly, to collate the conventional and advanced nueromarketing research approaches. And, highlight the merits and demerits of these approaches. Secondly, to understand the impulsive reactions of consumers to various situations in relation with the Paul MacLean's triune brain model.

4) Kumar (2015), "Neuromarketing: The New Science of Advertising"

This study clarify that "Neuromarketing is an emerging branch of neuroscience in which researchers use medical technology to determine consumer reactions to particular brands, slogans, and advertisements. By observing brain activity, researchers in lab-coats can predict whether you prefer Pepsi or Coke more accurately than you can. Critics have already begun to denounce the idea for its intrusiveness; however, though the field is already highly controversial, there is no doubt that it's continuing development will ultimately have a profound impact on consumerism and the overall study of human behaviour."

5) Ariely and Berns (2010), "Neuromarketing: the hope and hype of neuroimaging in Business" assume that the brain scanning techniques can provide indications regarding the basic preferences of an individual, which are more accurate than the data gathered by standard market research as these data are subject to prejudice due to a subjective approach to values. If this is true, the concepts and prototypes of the products could be quickly tested and the products which are not "promising" could be eliminated. This would result in a more efficient allocation of resources that could be used only for "promising" products.

6) Wilson et al. (2008) "Neuromarketing and consumer free will"

state that the use of neuromarketing could help buyers and marketing experts to understand each other better, but also to understand better the products they want, which leads to a win/win6 situation for both sides.

7) Lewis (2004), "Everything you wanted to know about neuromarketing but didn't know who to ask" affirms two most important techniques of analyzing human brain activities that are used in neuromarketing-fMRI and EEG:

- fMRI-Functional magnetic resonance imaging is the most frequent technique of scanning human brain in neuromarketing. The functional magnetic resonance is a technique using powerful magnetic and radio waves to create high-quality brain images.

- Ariely and Berns (2010) state that this technique uses MRI scanner to measure the level of oxygen in blood in certain brain areas. Changes in the oxygen 
level correlate with brain activity. The more active is a brain area, the more oxygen it requires, and this is recorded in 1152 minute detail by the scanner.

\section{Literature Review}

\subsection{Neuromarketing Defined}

The first man known to theorize neuromarketing was Peter Drucker, who claimed that the "main objective of neuromarketing is decoding the processes that take place in the consumer's mind, in order to discover the desires, wishes and the hidden causes of their options, so that there is a possibility to get them what they want" (Boricean, 2009: p. 119).

Many authors have defined Neuromarketing and some definitions are presented below;

1) Neuromarketing is the process of researching the brain patterns of consumers to reveal their responses to particular advertisements and products before developing new advertising campaigns and branding techniques (Collins Dictionary, 2017).

2) Neuromarketing is the study of the cerebral mechanism to understand the consumer's behavior in order to improve the marketing strategies (Smidts, 2002).

3) Neuromarketing aims to understand how consumers think and why the consumer chooses the products by applying "neuroscientific methods to analyze and understand human behavior in relation to markets and marketing exchanges" (Lee et al., 2007).

4) Neuromarketing is the application of findings from neuroscientific consumer research within the scope of managerial practice (Hubert \& Kenning, 2008).

5) Neuromarketing is mostly defined as a new field of marketing research studying consumers' cognitive and affective responses to different marketing stimuli (Zaltman \& Zaltman, 2008; Boricean, 2009; Zurawicki, 2010; Dooley, 2010).

6) Neuromarketing is the process that enables the knowledge and understanding of the mechanisms used by the human brain to process information (Georges \& Badoc, 2010).

7) Neuromarketing is a relatively new and controversial interdisciplinary research field, a component of marketing, by means of which one can properly interpret psychological and neurological knowledge necessary to understand customer behavior (Constensen, 2011).

8) Neuromarketing is defined as the obtaining of information useful for marketers by subjecting individuals to functional magnetic resonance imaging (fMRI) and other similar methods of studying automatic responses in the brain to certain stimuli, generally involving products and brands that are part of consumer culture (Berger, 2011).

9) Neuromarketing refers to those cutting edge methods for directly probing minds without requiring cognitive or conscious participation (Morin, 2011). 
10) Neuromarketing is a new marketing field that uses medical technologies like Nuclear Magnetic Resonance (NMR) to study the brain response to marketing stimuli (Dragolea \& Cotirlea, 2011).

11) Neuromarketing is a subset of the study of neuroeconomics, which combines neuroscience, genetics, economics, and psychology to understand how specific neuron activation may lead to larger scale market behavior (Levallois et al., 2012).

12) Neuromarketing is a means to describe the activity of the brain under the impact of marketing stimuli, which, by means of specific tools, correlates with the psychological reaction following subjects' exposure to certain ads (Kotler et al., 2009; Kotler \& Keller, 2012).

13) Neuromarketing can simplistically be defined as any marketing or market research activity, which uses methods, techniques or insights from the field of brain science (Genco et al., 2013).

14) Neuromarketing is widely defined as the science that uses MRI (magnetic resonance imaging), EEG (electroencephalography), TMS (transcranial magnetic stimulation), fMRI (functional magnetic resonance imaging) and other brain wave tools to view the human brain's responses to marketing stimuli to figure out what customers' thoughts are toward a product, service, advertisement, or even packaging to perfectly construct marketing campaigns that are based on the human brain's response (Hammou et al., 2013).

15) Neuromarketing is a portmanteau of "neuroscience" and "marketing". Neuromarketing technique offers an eclectic approach to wide availability of innovative technologies acknowledging more detailed analysis of neurological and psycho-physiological parameters (Stasi et al., 2018). Despite the various definitions of Neuromarketing available in literature in this article, we define neuromarketing is "the application of neuroscientific methods to analyze and understand human behavior in relation to markets and marketing exchanges.

By introducing it, scientists moved the focus from the solely commercial interest to the broader understanding of neuromarketing.

\subsection{What Is Neuromarketing?}

What makes neuromarketing appealing for the companies round the world is the notion of being able to peek into "the black box", or, in other words, the unconscious processes of consumer decision making (Fugate, 2007). Science claim that people use only $20 \%$ of their brain consciously; the rest is the unconscious part that neuromarketing is targeting to explore (Morin, 2011). The idea is supported by the so called "ironic revelation", the colorful images of the working "buying" brain, provided with the help of technology and the methods borrowed from the neuroscience (Schneider \& Woolgar, 2012; Green \& Holbert, 2012).

Neuromarketing uses disciplines such as neuroanatomy, neurology, neuropsychology, neuroendochrinology, cognitive neurosciences and neuroeconomy 
(Boricean, 2009: p. 120). All the disciplines combined together help marketers make sense of consumer decision making and empower them to understand what triggers the positive response for the stimuli. The methods used in these disciplines reveal what our bodies betray-starting with blood flows in different parts of the brain, ending with hormone emissions in the different parts of the body.

\subsection{Neuromarketing Techniques}

Neuromarketing specific technology and methodology are based on some very accurate instruments.

According to Pradeep (2010) and Barkin (2013), the most popular methods that neuromarketers apply for their clients can be classified as follows:

1) Electroencephalography (EEG). The good thing about EEG is that it allows to get a real-time image of what is happening in the respondent's brain. It measures the level of engagement and attentiveness with the help of the electrode cap put on the subject's scalp. The method captures the activity of the brain by measuring the electrodes firing. Another advantage of EEG is that the machine is portable and it's easy to transport it anywhere the researcher likes-even to supermarket. However, EEG machine, in contrary to fMRI scanner, measures only the signals outside the brain, therefore, it is sometimes hard to tell which part of the brain the signal is coming from (Zurawicki, 2010: p. 48).

2) Functional magnetic resonance imaging (fMRI). It shows which part of the brain is active when responding to a particular stimulus. However, fMRI scans do not show the real-time image. The image in the fMRI machine can be up to 5 seconds late from the real response in the brain, therefore, it is very hard to interpret (Pradeep, 2010). The lag is due to that machine measures blood flows in the brain and it takes a few seconds for blood to reach the working brain part. In fact, the fMRI machine, just like any other, does not show what you are thinking or feeling; it measures BOLD signal or, in other words, Blood Oxygen Level Dependant signal (Zurawicki, 2010: p. 44; Morin, 2011: p. 134). It shows the amount of oxygen-free hemoglobin in the particular parts of the brain-if the levels of "deoxyhemoglobin" are low, then that part is "lighting up" in the screen (Zurawicki, 2010: p. 44).

In addition, the use of the fMRI machine can cost up to "thousands of dollars an hour" (Barkin, 2013: p. 49), making this method available only for a few.

3) Biometrics:

a) Advanced polygraph. This method enables scientists to see different responses of the body, such as blood pressure, pulse, facial muscle movements and body movements. One of the most popular measurements is galvanic skin response (GSC), which shows the state of respondent's arousal. Unfortunately, these are "lagging indicators" (Pradeep, 2010: p. 14) that make measurements limited for marketing research. Therefore, it is quite usual to use advanced polygraph methods as the confirmatory data source to EEG examination. 
b) Eye-tracking. With the help of cameras, eye movements are tracked. The method shows where exactly the subject is looking when the advertisement displays. Combined with EEG it is best suited to measure visual forms of advertisements like videos, posters or packaging

c) Voice layering. The voice of the respondent is recorded and measured in comparison to oxygen-high and oxygen-low blood flows in the brain.

While measuring the subject with these methods, additional questions are sometimes given. The respondents are asked to compare, to express opinion or preference to the images, objects, sounds presented (Barkin, 2013).

In addition to the methods described, there are others like MRI (magnetic resonance imaging), NIRS (near infrared spectroscopy), PET (positron emission tomography), MEG (magneto encephalography), TMS (transcranial magnetic stimulation), etc. However, these methods have not gained popularity so far because of the high costs, quality of information they provide or inconvenience of use.

\subsection{Competitiveness}

Competitiveness is defined in dictionaries as the ability of successful competing in some way over time. In the literature the word "competitiveness" conveys a different meaning when applied to an individual firm or an individual sector or economic activity within a country or region. For a firm, competitiveness is the ability to produce the right goods and services of the right quality, at the right price, at the right time. It means meeting customers' needs more efficiently and more effectively than other firms do (Edmonds 2000: p. 20). Generally, competitiveness is the ability of an organization to compete successfully with its commercial rivals (Law, 2009).

Feurer and Chaharbaghi (1994) have proposed a holistic definition of competitiveness, taking into account the sustainability: "Competitiveness is relative and not absolute". It depends on shareholder and customer values, financial strength which determines the ability to act and react within the competitive environment and the potential of people and technology in implementing the necessary strategic changes. Competitiveness can only be sustained if an appropriate balance is maintained between these factors which can be of a conflicting nature" Snieška and Bruneckiene (2009: p. 46) have defined a regional competitiveness as an ability to use factors of competitiveness in order to make a competitive position and maintain it among other regions.

The organisation for Economic Co-operation and Development (OECD) suggested that competitiveness be understood as: "The ability of companies, industries, regions, nations or supranational regions to generate, while being and remaining exposed to international competition, relatively high factor income and factor employment levels on a sustainable basis" (Hatzichronoglou, 1996: p. 20). According to the OECD, competitiveness is the ability of a country to produce goods and services, under free and equalmarket conditions, that pass the test of 
the international market and at the same time ensure long-term growth of living standards (Economic Policy Reforms 2010: Going for Growth. 2010).

The National Competitiveness Council (NCC) in Ireland generally understands competitiveness as the ability of enterprises to successfully sell goods and services on international markets. Competitiveness is a crucial determinant of national economic survival and future prosperity (Our Cities: Drivers of National Competitiveness 2009).

The US Competitiveness Policy Council (1998) defines competition as the capability of producing goods/services at an international quality that can compete at international markets, resulting continuous increase in the welfare of a nation.

From Porter (1990) point of view should be a further emphasis on the productive use of resources in a nation as a good measure for competitiveness. DC (2001) stated that Competitiveness involves "a combination of assets and processes, where assets are inherited (natural resources) or created (infrastructure) and processes transform assets to achieve economic gains from sales to customers. Some authors view competitiveness with the competency approach.

They emphasized on the role of internal factors of the firms to enhance competitiveness such as firm strategy, structures, competencies, capabilities to innovate, and other tangible and intangible resources for their competitive success (Bartlett \& Ghoshal, 1989; Doz \& Prahalad, 1987; Hamel \& Prahalad, 1989, 1990). The ability to develop capabilities and talents far more effectively than competitors can help in achieving world-class competitiveness (Smith, 1995). Johnson (1992) declared that for providing greater value and satisfaction for customers than their competitors, companies must be operationally efficient, cost effective, and quality conscious.

\section{Results and Discussion}

The descriptive analysis of the respondents was on the basis of management practices. Table 1 illustrates the descriptive statistical analysis which was used in order to know the impact of the application of neuromarketing on the competitiveness.

The mean of all the items was higher than 2.5 which shows non-neutral stance from respondents on all items. The higher mean values represent that the respondent's strong values for all the items.

From Table 1 we can show the highest mean of the table is neuromarketing techniques (3.17), which indicate that it is one of the most effective forces on the competitiveness.

Table 1. Descriptive statistics for evaluating of Neuromarketing.

\begin{tabular}{cccc}
\hline Variable & Mean & SD & N \\
\hline $\mathrm{X}_{1}$ (Neuromarketing Activities) & 3.06 & 0.796 & 120 \\
$\mathrm{X}_{2}$ (Neuromarketing Techniques) & 3.17 & 0.768 & 120 \\
\hline
\end{tabular}




\section{Correlation Analysis}

The Pearson correlation is used to determine the relationship between all the variables, SPSS is a beneficial tool to run the correlation between variables for finding insights about the relation and Strength.

For our study we used correlation analysis to test relationship and strength between different variable (Table 2 and Table 3 ).

From The correlation analysis we show that:

- There is a significant positive correlation between the independent variable (the application of neuromarketing activities) $\left(X_{1}\right)$ and dependent variable (competitiveness) ( $Y$ ) with $72.8 \%$. Indicating a high correlation.

- There is a significant positive correlation between Neuromarketing technology and techniques $\left(X_{2}\right)$ and competitiveness $(Y)$ with $91.9 \%$. Indicating a high correlation.

- From correlation tables we can conclude that $\left(X_{2}\right)$ Neuromarketing technology and techniques is more correlated with $(Y)$ than $\left(X_{1}\right)$ Neuromarketing activities.

- So we conclude that, there is a statistically significant relationship between the application of neuromarketing and competitiveness, it is clear to us that there is a positive correlation between the application of neuromarketing and competitiveness.

Test the research hypotheses

\section{Regression Analysis}

Regression could be used as a bivariate to predict two variables or as a multiple regression for checking multiple variables at the same time. In this article, the simple linear regression technique was used to test the research hypotheses.

The Table 4 gives us the R-value which represents the correlation between the observed values and predicted values of dependent variable. $\mathrm{R}$ square is called the coefficient of determination and it gives the adequacy of the model. Here value of $\mathrm{R}$ square is 0.844 which that the independent variable of the model can predict $84.4 \%$ of variance in dependent variable.

Table 5 gives the test results for the analysis of one way ANOVA. The results are given in three rows. The first row labeled as Regression gives the

Table 2. Shows the correlation between $\left(Y, X_{1}\right)$.

\begin{tabular}{cccc}
\hline & & $Y$ & $X_{1}$ \\
\hline $\mathrm{Y}$ & Pearson Correlation & 1 & $0.728^{* *}$ \\
& Sig. (2-tailed) & & 0.000 \\
& $\mathrm{~N}$ & 120 & 120 \\
$\mathrm{X} 1$ & Pearson Correlation & $0.728^{* *}$ & 1 \\
& Sig. (2-tailed) & 0.000 & 120 \\
\hline
\end{tabular}

${ }^{* *}$. Correlation is significant at the 0.01 level (2-tailed). 
Table 3. Shows the correlation between $\left(Y, X_{2}\right)$.

\begin{tabular}{cccc}
\hline & & $Y$ & $X_{2}$ \\
\hline & & & \\
$\mathrm{Y}$ & Pearson Correlation & 1 & $0.919^{* *}$ \\
& Sig. (2-tailed) & & 0.000 \\
& $\mathrm{~N}$ & 120 & 120 \\
$\mathrm{X} 2$ & Pearson Correlation & $0.919^{* *}$ & 1 \\
& Sig. (2-tailed) & 0.000 & 120 \\
\hline
\end{tabular}

**. Correlation is significant at the 0.01 level (2-tailed).

Table 4. Model summary.

\begin{tabular}{cccccc}
\hline Model & $\mathrm{R}$ & R Square & Adjusted R Square & Std. Error of the Estimate & Durbin-Watson \\
\hline 1 & $0.920^{\mathrm{a}}$ & 0.847 & 0.844 & 0.3029418 & 1.716 \\
\hline
\end{tabular}

a. Predictors: (Constant), $X_{1}, X_{2}$; b. Dependent Variable: $Y$.

Table 5. ANOVA.

\begin{tabular}{ccccccc}
\hline \multicolumn{1}{c}{ Model } & Sum of Squares & Df & Mean Square & F & Sig. \\
\hline \multirow{3}{*}{1} & Regression & 59.486 & 2 & 29.743 & 324.090 & $0.000^{\mathrm{a}}$ \\
& Residual & 10.738 & 117 & 0.092 & & \\
Total & 70.223 & 119 & & & \\
\hline
\end{tabular}

a. Predictors: (Constant), $X_{1}, X_{2}$; b. Dependent Variable: $Y$.

variability in the model due to known reasons. The second row labeled residual gives variability due to random error and unknown reasons. F-value in this case is 324.090 and the sig is given by 0.000 which is less than 0.05 so we conclude that there is a statistically significant relationship between the application of neuromarketing and competitiveness (Table 6).

\section{From regression tables we can conclude:}

The R squared, was (84.7\%) also called coefficient of determination, is a statistical calculation that measures the degree of interrelation and dependence between two variables. In other words, it is a formula that determines how much a variable's behavior can explain the behavior of another variable.

The regression model, variables can be independent, which are used as the predictor or causal input and dependent, which are used as response variables. In experimental studies, independent variable $X$ is the variable that can be controlled and variable $Y$ is the variable that reflects the changes in the independent variable $X$.

And the regression model in our research will be:

$$
Y=0.256+0.078 X_{1}+0.858 X_{2}+E
$$

where:

$Y$ : competitiveness 
Table 6. Source: statistical analysis results (s p.s.s).

\begin{tabular}{|c|c|c|c|c|c|c|}
\hline \multicolumn{7}{|c|}{ Coefficients $^{\mathrm{a}}$} \\
\hline & \multirow{2}{*}{ Model } & \multicolumn{2}{|c|}{ Unstandardized Coefficients } & \multirow{2}{*}{$\begin{array}{c}\text { Standardized Coefficients } \\
\text { Beta }\end{array}$} & \multirow{2}{*}{$\mathrm{t}$} & \multirow{2}{*}{ Sig. } \\
\hline & & B & Std. Error & & & \\
\hline & (Constant) & 0.256 & 0.122 & & 2.097 & 0.038 \\
\hline \multirow[t]{2}{*}{1} & $X_{1}$ & 0.078 & 0.053 & 0.081 & 1.465 & 0.146 \\
\hline & $X_{2}$ & 0.858 & 0.055 & 0.858 & 15.570 & 0.000 \\
\hline
\end{tabular}

a. Dependent Variable: Y.

$X_{1}$ : Neuromarketing activities.

$X_{2}$ : Neuromarketing technology and techniques.

$E$ : is the error term.

The findings showed that there was a significant a positive correlation between the application of neuromarketing and competitiveness.

The finding showed that there was a significant positive correlation between the application of neuromarketing activities and competitiveness.

The finding showed that there was a significant positive correlation between the neuromarketing technology and techniques and competitiveness.

\section{Results of hypothesis tests}

In this article, the simple linear regression technique was used to test the research hypotheses.

\section{Main Hypothesis}

"There is a significance relationship between the application of neuromarketing and competitiveness in real estate marketing companies".

The findings showed that there is a positive correlation between the application of neuromarketing and competitiveness in real estate marketing companies, which means accepting the main hypothesis.

Sub hypotheses (a):

$\mathrm{H}$ (a): There is significance relationship between the application of neuromarketing activities and competitiveness.

The findings showed that there is a positive correlation between the application of neuromarketing activities and competitiveness in real estate marketing companies, which means accepting the sub hypothesis (a).

Sub hypotheses (b):

$\mathrm{H}(\mathrm{b})$ : There is significance relationship between the application of neuromarketing technology and techniques and competitiveness.

The findings showed that there is a positive correlation between the application of neuromarketing technology and techniques and competitiveness.

\section{Results}

Marketing has changed in recent years. It can be said that it has become more focused on individuals and their needs. The change has been encouraged by the 
emergence of a new branch of marketing called the neuromarketing.

It is a public secret that markets are increasingly competitive, global and complex. Therefore, neuromarketing can be viewed as an opportunity for many companies that really want to "make the difference" in the market because the main objective of neuromarketing techniques is to properly comprehend the neuroscience and add value to the companies in the way they manage new trends, developments and tendencies.

Thus, the competitive advantage gained by those using neuromarketing gives the consumer added value and thus they will ultimately be more satisfied with the product or service. Therefore, neuromarketing serves the purpose of improving how companies create products and advertise them in order to become more interesting, appealing and valuable for consumers (Nyoni \& Bonga, 2017).

There is a significant positive correlation between $(Y)$ and $\left(X_{1}\right)$ with $72.8 \%$.

There is a significant positive correlation between neuromarketing technology and techniques $\left(X_{2}\right)$ and competitiveness $(Y)$ with $91.9 \%$ this confirmed by a study (Fugate, 2007).

From correlation tables we can conclude that $\left(X_{2}\right)$ neuromarketing technology and techniques is more correlated with $(Y)$ than $\left(X_{1}\right)$ neuromarketing activities.

So we conclude that, there is a statistically significant relationship between the application of neuromarketing and competitiveness, it is clear to us that there is a positive correlation between the application of neuromarketing and competitiveness this confirmed by (Ariely \& Berns, 2010, Williamson, 2002; Lee et al., 2007; Fugate, 2007; Wilson et al., 2008; Wang \& Minor, 2008; Hubert \& Kenning, 2008).

The study has found a positive relationship between the application of neuromarketing and competitiveness in real estate marketing companies in Egypt; thus, real estate marketing companies should make efforts to increase their competitiveness in the market by the application of neuromarketing system as a new and critical strategy to understand the needs and thoughts of the customers then they gain customers' satisfaction and loyalty.

Real estate marketing companies should also focus on competitiveness by enhancing internal competitiveness (i.e., improve the standers of employees selection, development, rewards, and recognition). Consequently, employee satisfaction will lead to external competitiveness.

\section{Recommendations}

Real estate marketing companies should introduce new innovative services by the most popular methods that neuromarketers apply for their clients can be classified as follows:

- Electroencephalography (EEG). The good thing about EEG is that it allows to get a real-time image of what is happening in the respondent's brain. It measures the level of engagement and attentiveness with the help of the electrode cap put on the subject's scalp. The method captures the activity of the 
brain by measuring the electrodes firing. Another advantage of EEG is that the machine is portable and it's easy to transport it anywhere the researcher likes-even to supermarket. However, EEG machine, in contrary to fMRI scanner, measures only the signals outside the brain, therefore, it is sometimes hard to tell which part of the brain the signal is coming from (Zurawicki, 2010: p. 48).

- Functional magnetic resonance imaging (fMRI). It shows which part of the brain is active when responding to a particular stimulus. However, fMRI scans do not show the real-time image. The image in the fMRI machine can be up to 5 seconds late from the real response in the brain, therefore, it is very hard to interpret (Pradeep, 2010). The lag is due to that machine measures blood flows in the brain and it takes a few seconds for blood to reach the working brain part. In fact, the fMRI machine, just like any other, does not show what you are thinking or feeling; it measures BOLD signal or, in other words, Blood Oxygen Level Dependant signal (Zurawicki, 2010: p. 44; Morin, 2011: p. 134). It shows the amount of oxygen-free hemoglobin in the particular parts of the brain-if the levels of "deoxyhemoglobin" are low, then that part is "lighting up" in the screen (Zurawicki, 2010: p. 44).

Real estate marketing companies should also focus on competitiveness by enhancing the application of neuromarketing activities and techniques to ease the access to the customers.

As neuromarketing becomes more prominent and gains more insight into consumer minds, it is recommendable that neuromarketing companies strictly comply with strict written down laws, regulations and standards.

Neuromarketing companies should address both professional and ethical dilemmas in line with both local and internationally recognized neuromarketing industry standards.

Neuromarketing should take a more active role in education, medicine, business as well as socio-economic and political policy in order for both the business and academic community to maneuver this discipline more sincerely for the benefit of both the consumer and the businessman.

For neuromarketing to grow as a fully-fledged discipline, it should be viewed in a way that is easily understandable by not only the neurologists, marketing researchers, advertising psychologists, product design \& development consultants and advertising executives but also by the business owners who may seek to use neuromarketing in their next advertising campaign, brand development, product design or rebranding and the consumer who will be a potential test subject in the research.

\section{Conclusion}

The study examines "relationship between the application of neuromarketing and competitiveness in real estate companies." This study was guided by objectives and three research questions, three hypotheses were proposed (one main 
hypothesis and two sub hypotheses). The dimensions of neuromarketing in real estate companies were identified from extent literature which includes the application of neuromarketing activities and the application of neuromarketing technology and techniques. Furthermore, the application of neuromarketing and competitiveness was investigated. A research framework was developed relating to the application of neuromarketing and competitiveness. The application of neuromarketing exerted a significant and a strong relationship with competitiveness.

\section{Future Research}

Neuromarketing is a new phenomenon discussed in scientific literature and applied to practical marketing research. Therefore, many more studies are needed to explore the subject.

It is also important to carry out studies in other parts of the world and see how neuromarketing is consumed in other cultural contexts.

One could do a comparative research between two countries or regions and find out similarities and differences in the use of neuromarketing.

\section{Conflicts of Interest}

The authors declare no conflicts of interest regarding the publication of this paper.

\section{References}

Agarwal, S., \& Dutta, T. (2015). Neuromarketing and Consumer Neuroscience: Current Understanding and the Way Forward. Decision, 42, 457-462.

https://doi.org/10.1007/s40622-015-0113-1

Ariely, D., \& Berns, G. (2010). Neuromarketing: The Hope and Hype of Neuroimaging in Business. Nature Reviews Neuroscience, 11, 284-292. https://doi.org/10.1038/nrn2795

Barkin, E. (2013). The Prospects and Limitation of Neuromarketing. Customer Relationship Management, 46-50.

Bartlett, A., \& Ghoshal, S. (1989). Managing across Borders. Boston, MA: Harvard Business School Press.

Berger, A. A. (2011). Neuromarketing. In D. Southerton (Ed.), Encyclopedia of Consumer Culture (pp. 1040-1041). Thousand Oaks, CA: Sage Publications. https://doi.org/10.4135/9781412994248.n383

Boricean, V. (2009). Brief History of Neuromarketing. The International Conference of Administration and Business, 14-15 November 2009, 119-121.

Calvert, G. A., \& Thensen, T. (2004). Multisensory Integration: Methodological Approaches and Emerging Principles in the Human Brain. Journal of Psychology, 98, 191-205. https://doi.org/10.1016/j.jphysparis.2004.03.018

Collins Dictionary (2017). http://www.collinsdictionary.com.neuromarketing/

Constensen, A (2011). Neuromarketing, Umsatzsteigerung durch Neurosychologysche Kundenanalyse. Mauritius: Fastbook Publishing.

Dinu, G., Tanase, A. C., Dinu, L., \& Tanase, F. D. (2010). The New Techniques for Han- 
dling Consumer Behaviour. Annals of DAAAM \& Proceedings, 21, 1115.

Doz, Y. L., \& Prahalad, C. K. (1987). The Multinational Mission. New York: The Free Press.

Dragolea, L., \& Cotirlea, D. (2011). Neuromarketing-Between Influence and Manipulation. Polish Journal of Management Studies, 3, 78-88.

Edmonds, T. (2000). Regional Competitiveness \& the Role of the Knowledge Economy. House of Commons Library, Research Paper, London: Research Publications Office, 73-55.

Egidi, G., Nusbaum, H. C., \& Cacioppo, J. T. (2008). Neuroeconomics: Foundational Issues and Consumer Relevance. In C. Haugvedt, F. Kardes, \& P. Herr (Eds.), Handbook of Consumer Psychology (pp. 1177-1214). Mahwah, NJ: Erbaum.

Feurer, R., \& Chaharbaghi, K. (1994). Defining Competitiveness: A Holistic Approach. Management Decision, 32, 49-58. https://doi.org/10.1108/00251749410054819

Fisher, C., Chin, L., \& Klitzman, R. (2010). Defining Neuromarketing: Practices and Professional Challenges. Harvard Review of Psychiatry, 18, 230-237.

https://doi.org/10.3109/10673229.2010.496623

Fugate, D. L. (2007). Neuromarketing: A Layman's Look at Neuroscience and Its Potential Application to Marketing Practice. Journal of Consumer Marketing, 24, 385-394. https://doi.org/10.1108/07363760710834807

Garcia, J. R., \& Saad, G. (2008). Evolutionary Neuromarketing: Darwinizing the Neuroimaging Paradigm for Consumer Behavior. Journal of Consumer Behaviour, 7, 397-414. https://doi.org/10.1002/cb.259

Genco, S. J., Pohlman, A. P., \& Steidl, P. (2013). Neuromarketing for Dummies (1st ed.). Mississauya, ON: John Wiley \& Sons.

Georges, P., \& Badoc, M. (2010). Le neuromarketingen action. Parleretvedre au cerveau. Paris: EYROLLES-Editions d'Organisation.

Hamel, G., \& Prahalad, C. K. (1989). Strategic Intent. HBR, No. 3, 63-76.

Hammou, K. A., Galib, H., \& Melloul, J. (2013). The Contributions of Euromarketing in Marketing Research. Journal of Management Research, 5, 20-23. https://doi.org/10.5296/jmr.v5i4.4023

Hatzichronoglou, T. (1996). Globalisation and Competitiveness: Relevant Indicators. OECD Science, Technology and Industry Working Papers 5, 62.

http://iiii.ir/press/up-content/uploads/2012/08/Leon-Zurawicki-euromarketing-Explor ing-the-Brain-of-the-consumer-2010.pdf

Hubert, M., \& Kenning, P. (2008). A Current Overview of Consumer Neuroscience. Journal of Consumer Behavior, 7, 272-292. https://doi.org/10.1002/cb.251

Johnson, H. T. (1992). Relevance Regained. New York, NY: The Free Press.

Kenning, P., \& Linzmajer, M. (2011). Consumer Neuroscience: An Overview of an Emerging Discipline with Implications for Consumer Policy. Journal für Verbraucherschutz und Lebensmittelsicherheit, 6, 111-125. https://doi.org/10.1007/s00003-010-0652-5

Kotler, P., \& Keller, K. L. (2012). Marketing Management (14th Global ed.). Upper Saddle River, NJ: Pearson.

Kotler, P., Keller, K. L., Brandy, M., Goodman, M., \& Hansen, T. (2009). Marketing Management. London: Pearson Harlow, Prentice Hall,.

Krajinovic, A., Sikiric, D., \& Jasic, D. (2012). Neuromarketing and Consumers' Free Will. MIC 2012, Management International Conference, Management Transformation with 
Creativity, 13th International Conference, Budimpešta, Mađarska, 22-24 November 2012, 1143-1163.

Kumar, S. (2015). Neuromarketing: The New Science of Advertising. Universal Journal of Management, 3, 524-531. https://doi.org/10.13189/ujm.2015.031208

Kumlehn, M. (2011). Consumer Neuroscience: Pricing Research to Gain and Sustain a Cutting Edge Competitive Advantage by Improving Customer Value and Profitability. https://doi.org/10.2139/ssrn.1872325

Law, J. (2009). A Dictionary of Business and Management (5 ed.). Oxford: Oxford University Press.

http://www.oxfordreference.com/views/ENTRY.html?subview=Main\&entry=t18.e1333

Lee, N., Broderick, A. J., \& Chamberlain, L. (2007). What Is "Neuromarketing"? A Discussion and Agenda for Future Research. International Journal of Psychophysiology, 63, 199-204. https://doi.org/10.1016/j.ijpsycho.2006.03.007

Levallois, C., Clithero, J. A., Wouters, P., Smidts, A., \& Huettel, S. A. (2012). Translating Upwards: Linking the Neural and Social Sciences via Neuroeconomics. Nature Reviews, Neuroscience, 13, 789-797. https://doi.org/10.1038/nrn3354

Lewis, D. (2004). Everything You Wanted to Know about Neuromarketing but Didn't Know Who to Ask. Journal of Advertising Research.

Morin, C. (2011). Neuromarketing: The Neuroscience of Consumer Behavior. Society, 48, 131-135. https://doi.org/10.1007/s12115-010-9408-1

Murphy, E., Illes, J., \& Reiner, P. (2008). Neuroethics of Neuromarketing. Journal of Consumer Behaviour, 7, 293-302. https://doi.org/10.1002/cb.252

Nemorin, S., \& Gandy Jr., O. H. (2017). Exploring Neuromarketing and Its Reliance on Remote Sensing: Social and Ethical concerns. International Journal of Communication, $11,4824-4844$.

Nyoni, T., \& Bonga, W. G. (2017). Neuromarketing: No Brain, No Gain! Journal of Economics and Finance, 2, 17-29.

Orzan, G., Zara, I. A., \& Purcarea, V. L. (2012). Neuromarketing Techniques in Pharmaceutical Drugs Advertising-A Discussion and Agenda for Future Research. Journal of Medicine and Life, 5, 428-432.

Pop, A. N., Dabija, D. C., \& Iorga, A. M. (2014). Ethical Responsibilities of Neuromarketing Companies in Harnessing the Market Research-A Global Exploratory Approach. Amfiteatru Economic, XVI, 26-40.

Porter, M. E. (1990). The Competitive Advantage of Nations. London: Macmillan.

Pradeep, A. K. (2010). The Buying Brain: Secrets for Selling to the Subconscious Mind. Hoboken, NJ: John Wiley \& Sons.

Ramsoy, T. Z. (2014). Introduction to Neuromarketing and Consumer Science (Kindle ed.). Neurons Inc.

Renvoise, P., \& Morin, C. (2007). Neuromarketing: Understanding the Buy Buttons in Your Customer's Brain. New York: HarperCollins Leadership.

Roebuck, K. (2011). Neuromarketing: High-Impact Strategies-What You Need to Know: Definitions, Adoptions, Impact, Benefits, Maturity, Vendors. Brisbane: Emereo Publishing.

Sebastain, V. (2014). New Directions in Understanding the Decision-Making Process: Neuroeconomics and Neuromarketing. Procedia-Social and Behavioral Sciences, 127, 758-762. https://doi.org/10.1016/j.sbspro.2014.03.350

Shukla, S. (2019). Neuromarketing: A Change in Marketing Tools and Techniques. In- 
ternational Journal of Business Forecasting and Marketing Intelligence, 5, 267-284. https://doi.org/10.1504/IJBFMI.2019.104044

Smidts, A. (2000). Look in the Brain on the Possibilities of Neuromarketing, Inaugural Addresses, Research in Management Series. Erasmas Research Institute of Management.

Smith, S. (1995). World Class Competitiveness. Managing Service Quality, 5, 36-42. https://doi.org/10.1108/09604529510100387

Snieška, V., \& Bruneckiene, J. (2009). Measurement of Lithuanian Regions by Regional Competitiveness Index. Engineering Economics, 1, 45-57.

Solomon, M. R. (2008). O Comportamento do Consumidor: Comprando, Possuindo e Sendo. Porto Alegre: Bookman.

Stanton, S. J., Sinnott-Armstrong, W., \& Huettel, S. A. (2016). Neuromarketing: Ethical Implications of Its Use and Potential Misuse. Journal of Business Ethics, 144, 799-811. https://doi.org/10.1007/s10551-016-3059-0

Suomala, J. et al. (2012). Neuromarketing: Understanding Customer Subconscious Responses to Marketing. Technology Innovation Management Review, 2, 12-21. https://doi.org/10.22215/timreview/634

The US Competitiveness Policy Council (1998). Building a Competitive America. First Report to the President and Congress.

Ulman, Y. I., Cakar, T., \& Yildiz, G. (2015). Ethical Issues in Neuromarketing: "I Consume, Therefore I Am!”. Science and Engineering Ethics, 21, 1271-1284.

van Arendonk, E., \& Polderman, A. (2013). Neuromarketing, Maximale Impact met marketing en communicatie. Amsterdam: Boom uitgevers Amsterdam.

Verhoef, P. C., \& Leeflang, P. S. (2009). Understanding the Marketing Department's Influence within the Firm. Journal of Marketing, 73, 14-37.

https://doi.org/10.1509/jmkg.73.2.14

Vlăsceanu, S. (2014a). Neuromarketing and Evaluation of Cognitive and Emotional Responses of Consumers to Marketing Stimuli. Procedia-Social and Behavioral Sciences, 127, 753-757. https://doi.org/10.1016/j.sbspro.2014.03.349

Vlăsceanu, S. (2014b). New Directions in Understanding the Decision-Making Process: Neuroeconomics and Neuromarketing. Procedia-Social and Behavioral Sciences, 127, 758-762. https://doi.org/10.1016/j.sbspro.2014.03.350

Wang, Y. J., \& Minor, M. S. (2008). Validity, Reliability, and Applicability of Psychophysiological Techniques in Marketing Research. Psychology \& Marketing, 25, 197-232. https://doi.org/10.1002/mar.20206

Williamson, M. (2002). Emotions, Reason and Behavior: A Search or the Truth. Journal of Consumer Behaviour, 2, 196-202. https://doi.org/10.1002/cb.100

Wilson, M., Gaines, J., \& Hill, R. (2008). Neuromarketing and Consumer Free Will. Journal of Consumer Affairs, 42, 389-410.

http://class.classmatandread.net/Physio/neurofreewill.pdf https://doi.org/10.1111/j.1745-6606.2008.00114.x

Wyer Jr., R. S., \& Xu, A. J. (2010). The Role of Behavioral Mind-Sets in Goal-Directed Activity: Conceptual Underpinnings and Empirical Evidence. Journal of Consumer Psychology, 20, 107-125. https://doi.org/10.1016/j.jcps.2010.01.003

Zaltman, G., \& Zaltman, L. (2008). Marketing Metaphoria. Cambridge, MA: Harvard Business Press.

Zurawicki, L. (2010). Neuromarketing: Exploring the Brain of the Consumer. Switzerland: Springer. https://doi.org/10.1007/978-3-540-77829-5 